San Jose State University

SJSU ScholarWorks

Master's Projects

Master's Theses and Graduate Research

8-4-2009

\title{
Perceptions Among Students in Online Health Related Courses - A Pilot Study
}

Kathy Sullivan

San Jose State University

Follow this and additional works at: https://scholarworks.sjsu.edu/etd_projects

Part of the Other Nursing Commons

\section{Recommended Citation}

Sullivan, Kathy, "Perceptions Among Students in Online Health Related Courses - A Pilot Study" (2009). Master's Projects. 818. DOI: https://doi.org/10.31979/etd.behy-g79z

https://scholarworks.sjsu.edu/etd_projects/818

This Master's Project is brought to you for free and open access by the Master's Theses and Graduate Research at SJSU ScholarWorks. It has been accepted for inclusion in Master's Projects by an authorized administrator of SJSU ScholarWorks. For more information, please contact scholarworks@sjsu.edu. 


\section{SAN JOSE STATE UNIVERSITY \\ SCHOOL OF NURSING}

\section{MASTER'S PROGRAM PROJECT OPTION (PLAN B) \\ PROJECT SIGNATURE FORM}

STUDENT NAME_ Kathy Sullivan

SEMESTER ENROLLED___ Summer 2009

TITLE OF PROJECT__Perceptions Among Students in Online

Health Related Courses - A Pilot Study

\section{NAME OF JOURNAL_Journal of Nursing Education}

The project and manuscript have been successfully completed and meet the standards of the School of Nursing at San Jose State University. The project demonstrates the application of professional knowledge, clinical expertise, and scholarly thinking. An abstract of the project and two copies of the manuscript are attached.

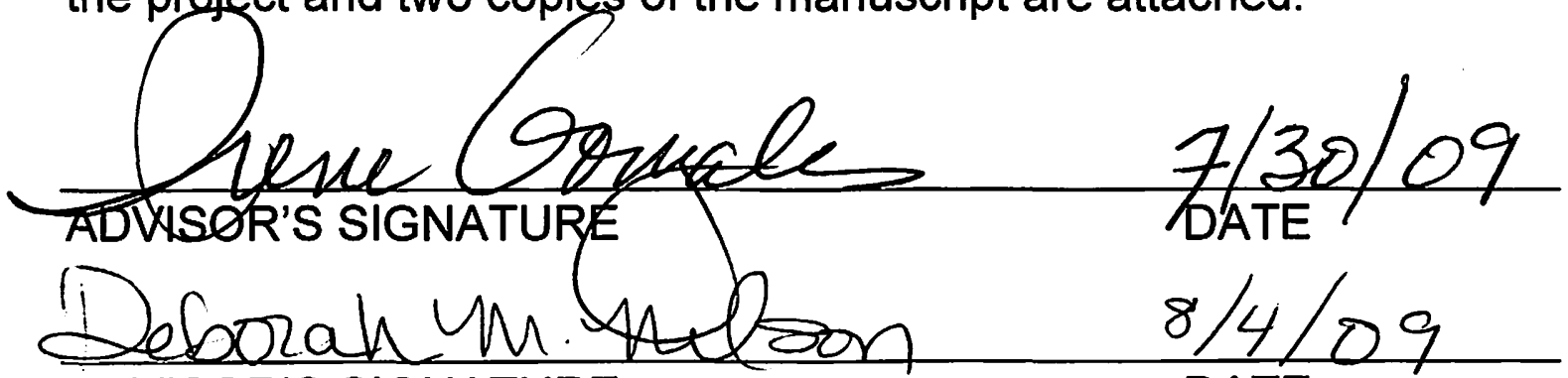

ADVISOR'S SIGNATURE

DATE

Please submit this form to the Graduate Coordinator. Attach abstract, two copies of the manuscript, and documentation of submission to the journal (i.e., Postal receipt)

JHC: Spring 2000 


\title{
Perceptions Among Students in Online Health Related Coursés - A Pilot Study
}

\author{
Kathy Sullivan \\ Dr. Irene Gonzales \\ Deborah Nelson
}

\begin{abstract}
Given the proliferation of online courses in university education, continuous evaluation is imperative to ensure quality. This study utilized a quantitative descriptive design using a questionnaire to explore the perceived adequacy and acceptance of distance learning in undergraduate health related courses. Questions were designed to elicit students' reactions to teaching methods, course content, and how the format influenced their learning.

Overall, acceptance of online courses is high. Most of the students were willing to take another online course in the future. Respondents felt that online courses offer more flexibility, encourage both independent and critical thinking skills, and that the course materials reinforce the learning process. Students also felt that educators were able to adequately explain concepts, provide sufficient assistance, and that the instruction was both current and at the appropriate level.
\end{abstract}

Both students and faculty will benefit from the study by helping to facilitate the improved quality of online courses. 
Perceptions Among Students in Online Health Related Courses - A Pilot Study

\author{
A Paper Presented to \\ The Faculty of the School of Nursing \\ San Jose State University
}

In Fulfillment of the

Requirements for the Course

NURS 297

By

Kathy Sullivan

August 4, 2009 


\title{
Perceptions Among Students in Online Health Related Coursés - A Pilot Study
}

\author{
Kathy Sullivan \\ Dr. Irene Gonzales \\ Deborah Nelson
}

\begin{abstract}
Given the proliferation of online courses in university education, continuous evaluation is imperative to ensure quality. This study utilized a quantitative descriptive design using a questionnaire to explore the perceived adequacy and acceptance of distance learning in undergraduate health related courses. Questions were designed to elicit students' reactions to teaching methods, course content, and how the format influenced their learning.

Overall, acceptance of online courses is high. Most of the students were willing to take another online course in the future. Respondents felt that online courses offer more flexibility, encourage both independent and critical thinking skills, and that the course materials reinforce the learning process. Students also felt that educators were able to adequately explain concepts, provide sufficient assistance, and that the instruction was both current and at the appropriate level.
\end{abstract}

Both students and faculty will benefit from the study by helping to facilitate the improved quality of online courses. 


\section{Background}

The nursing profession is facing a dire shortage which is expected to escalate as society ages and the demand for quality health care increases. By 2014 it is estimated that over 1.2 million new and replacement nurses will be needed (AACN, 2007). According to the American Association of Colleges of Nursing, the United States must graduate approximately $90 \%$ more nurses from U.S. nursing programs to meet the projected growth in demand for $\mathrm{RN}$ services (AACN, 2007).

In an effort to address the need to train increasingly more nurses, there has been a recent trend toward the use of online nursing instruction to meet students' needs concerning convenience and easy access to information. This web-based instruction in baccalaureate and graduate nursing education is expanding in colleges and universities across the country (Teeley, 2007; Wills \& Stommel, 2002; Woo \& Kimmick, 2000). The number of traditional college-age students has decreased while nontraditional part-time students who work and have family obligations have become the norm for most programs (Diekelmann \& Schulte, 2000; Seiler \& Billings, 2004; Sit et al, 2000; ). These online courses provide students more flexibility with self-paced learning as their schedules permit, reduce or eliminate travel time, as well as provide added opportunities for reviewing course materials (Billings, 2000; Leasure et al, 2000).

Numerous research studies suggest there is no significant difference between learning outcomes of online and traditional nursing courses (Bachman \& Panzarin, 1998; Billings \& Bachmeier, 1994; Leasure et al, 2000; Rosenblund et al, 1999; Woo \& Kimmick, 2000). However, continued evaluation of all aspects of online courses, from 
student learning to effectiveness of the course, instructor, and overall program, is essential (Palloff \& Pratt, 1999).

A combination of active participation, social interaction, and collaboration needs to take place if effective online learning is to occur (Alexander \& Boud, 2001). A major challenge in adopting the online learning model is to enhance human interaction in order to facilitate peer support, develop communicative dialogue, and encourage socialization (Sit et al, 2005). The nursing literature (Boyle \& Wamback 2001; Thiele, 2003; Thurmond, 2003) supports interaction as a core element of an effective online environment and found a direct correlation to improved student learning. Online environments must encourage participation while effectively promoting an interactive learning experience.

Findings (Leasure et al, 2000; Salyers, 2007; Wills \& Stommel, 2002) show that more than half of survey respondents preferred online teaching, mainly because of the enhanced level of interactivity between students and between students and educators in online courses. Students must actively interact and engage other students and the educator online to complete assignments. They found that locating help was much easier in online classes because the educator and other students are available online virtually around the clock (Hyde \& Murray, 2005). This virtual contact with the educator and other students may not be viewed positively by all students, as Halstead and Coudret (2000) reported in their study in which nursing students rated decreased physical contact with faculty and peers as a disadvantage of online learning. Another research study found that interactions with faculty were satisfying because the faculty members were easily 
accessible, but students considered the content of communication sterile and nonexpressive (Diekelmann \& Schulte, 2000).

Asynchronous discussions enabled by web-based learning tools and offered through online bulletin boards are a crucial part of the online environment to foster this necessary interaction and communication. Research shows that these discussion platforms improve quality and utilize high levels of analysis and critical thinking skills (Fearing \& Riley, 2005; Hyde \& Murray, 2005). Moreover, these communication forums provide an opportunity for peers to connect, share information, and collaborate on coursework. In contrast with the traditional classroom, where individual students can hide and not reveal their weaknesses, in the web-based environment students' work, including the discussion of course content, is available for scrutiny (Magnussen, 2006).

A body of literature has shown the communication between students and with the educator to be a crucial piece in online class satisfaction (Buckley, 2003; Fearing \& Riley, 2005; Sit et al, 2005). Studies indicated that the most important perceived course factors included the active learning strategies, ongoing communication, timely and constructive feedback, and flexibility of the asynchronous format (Fearing \& Riley, 2005; Halstead \& Coudret, 2000; Kenny, 2002; Leasure et al, 2000).

\section{Research Problem}

In an effort to address the need to train increasingly more nurses, there has been a recent trend toward the use of online nursing instruction to meet students' needs concerning convenience and easy access to information. As the use of web-based courses in nursing continues to increase, nursing educators are concerned with assuring the quality of the educational experiences and outcomes of their online programs. The 
Alliance for Nursing Accreditation (2003) states that distance delivered programs must meet the same accreditation criteria and academic standards as traditional on-site programs, and stress the need to develop methods for continuous quality improvement (Pyron et al, 2003).

The purpose of this study is to explore the perceived adequacy and acceptance of distance learning in the undergraduate health related courses using a self-administered online questionnaire. Students' perceptions of the effectiveness of their ability to learn in these online courses will also be assessed. The hypothesis is that on-line coursework is as effective as traditional classroom teaching for the courses studied.

The terms used throughout this research study will be defined as follows: online course/web-based course is a distance delivered format using the World Wide Web where students learn remotely and do not have face-to-face meetings after the initial one-time orientation; WebCT is an online virtual learning environment system which allows instructors to manage their course tools such as discussion boards, mail systems and live chat, documents and web pages.

Because of the recent proliferation of online courses in nursing education, it is important to assess whether the students feel that they are getting a valuable educational experience with these online classes. Answering the research questions will assist in the development of effective learning and teaching strategies. The information gathered will then be used to attract more students, keep current students satisfied, and provide for the development and expansion of quality online education programs. 


\section{Conceptual Framework}

The increased use of online learning technology in education is often seen as a result of the general shift toward adult learning theories in which the educator is viewed not as a distributor of content, but as a facilitator of learning and an assessor of learning outcomes (Ruiz et al, 2006). Web based technologies in education use adult learning theories that view instructors in the role of facilitator or resource rather than a lecturer or grader.

The theoretical framework employed in this research study is based on the adult learning theory of Andragogy proposed by Malcolm Knowles in 1950. Undergraduate nursing students fall into the category of adult learners who have higher expectations for the learning process and expect to be more actively involved in learning (Davenport, 1985).

Knowles developed the theory of Andragogy specifically for adult learning and emphasized that adults are self-directed and expect to take responsibility for decisions (Fisher \& Podeschi, 1989). Adult learning programs such as online courses must accommodate this fundamental aspect. Knowles outlined four crucial assumptions about the characteristics of adult learners that are different from the assumptions about child learners: adults need to know why they need to learn something, adults need to learn experientially, adults approach learning as problem-solving, and adults learn best when the topic is of immediate value (Davenport, 1985). Instruction for adults needs to focus more on the process and less on the content being taught.

Academic autonomy occurs when students learn how to regulate and direct their own behaviors so they can control and manage the outcomes of their performance in 
online instruction (Fisher \& Podeschi, 1989). Active learning approaches, in which the student is fully engaged in discovery learning, result in greater retention than more passive approaches. Experiential learning and an active engagement in the learning process are as important in the online environment as they have been in the traditional classroom (Magnussen, 2006).

\section{Methodology}

Participants in this research study were a convenience sample of $46(N=46)$ baccalaureate students between the ages of 20 and 55 and enrolled in one of the 37 health related online courses during the Spring 2009 semester at a local urban state university. A questionnaire was sent to the course instructors with a request to email the questionnaire to students enrolled in the selected classes. Anonymity was guaranteed to the professor and to the students.

A quantitative descriptive design using survey techniques was utilized. Data was obtained using the Mount Royal College's FAST (Free Assessment Summary Tool) evaluation tool specifically designed for the online learning environment. The Mount Royal College's FAST (Free Assessment Summary Tool) evaluation tool was developed by Dr. Bruce Ravelli, a sociology instructor at Mount Royal College, Calgary Alberta, Canada, and is contractually obligated to remain both free and available to any educators who use the software to survey the learning process until October 2011. All survey items were selected from the FAST database, which have been tested for validity and reliability. The questionnaire is composed of 24 survey items. The first six questions obtained demographic information about the student. The remaining questions were designed to elicit the students' reactions to internet teaching methods, the effect of 
working alone versus a classroom setting, the ability to adequately:cover appropriate course content in a distance learning environment, and the degree to which this format influenced their learning processes. The students were asked to respond to each of the questions by indicating whether they "Strongly Agree, Agree, Disagree or Strongly Disagree". An opportunity for comments was also provided.

Analysis of this non-parametric data was done using a Chi-Square Test (X2). Independent variables are the four answer choices presented to each survey respondent. If every response were equally probable, one fourth of the responses would appear in each category. The $\mathrm{X} 2$ test was used to determine if the differences in responses could be attributed to chance. A significant $\mathrm{X} 2$ value shows that the opinions are indeed significantly different that those expected by chance alone.

\section{Results}

The students' ages were equally divided between those who were 30 years or younger and those over 30 years of age. The younger group was clustered around 22-25 years and the older group 41-50 years. Most of the students were white (74\%), with the remainder divided between Hispanic (11\%) and Asian Pacific Islander (13\%). Most of the students $(87 \%)$ had enrolled in an on-line class before. Only thirteen percent $(13 \%)$ were taking an on-line class for the first time. One half of the students were currently working part time; the remainder was evenly divided between full-time employment and unemployed work status. Gender was not considered as only one male responded to the survey. Forty-six $(\mathrm{N}=46)$ undergraduate students responded to the survey. 


\section{Internet vs. Classroom Setting}

\begin{tabular}{|c|c|}
\hline \multicolumn{2}{|c|}{$\begin{array}{l}\text { Table } 1 \\
\text { The course flexibility assists me in meeting requirements. }\end{array}$} \\
\hline Strongly Agree & $46 \%$ \\
\hline Agree & $50 \%$ \\
\hline Disagree & $2 \%$ \\
\hline Strongly Disagree & $2 \%$ \\
\hline \multicolumn{2}{|c|}{$\begin{array}{l}\text { Table } 2 \\
\text { I am able to develop a relationship with my instructor even without } \\
\text { face-to-face meetings. }\end{array}$} \\
\hline Strongly Agree & $15 \%$ \\
\hline Agree & $50 \%$ \\
\hline Disagree & $22 \%$ \\
\hline Strongly Disagree & $9 \%$ \\
\hline Not Applicable & $4 \%$ \\
\hline
\end{tabular}

\begin{tabular}{|l|l|}
\hline \multicolumn{2}{|c|}{ Table 3 } \\
$\begin{array}{l}\text { Opportunities for assistance are available (e.g. office hours, } \\
\text { telephone, email or website. }\end{array}$ \\
\hline Strongly Agree & $43 \%$ \\
\hline Agree & $48 \%$ \\
\hline Disagree & $9 \%$ \\
\hline Strongly Disagree & $0 \%$ \\
\hline Not Applicable & $0 \%$ \\
\hline
\end{tabular}

\begin{tabular}{|l|l|}
\hline \multicolumn{2}{|c|}{ Table 4} \\
\begin{tabular}{|l|} 
Even without face-to-face interactions, my instructor is able to \\
explain concepts to assist my understanding.
\end{tabular} \\
\hline Strongly Agree & $28 \%$ \\
\hline Agree & $54 \%$ \\
\hline Disagree & $11 \%$ \\
\hline Strongly Disagree & $4 \%$ \\
\hline Not Applicable & $2 \%$ \\
\hline
\end{tabular}

One difference between scheduled classes and distance learning is that students can participate at their convenience. Nearly everyone (96\%) agreed that the internet course offered more flexibility than a traditional classroom setting $(X 2=246.4, p<.005)$. 
However, nearly a third of the students (31\%) felt that without face to face contact they were unable to develop a personal relationship with their educator $(X 2=19.1, p<.005)$.

Still, ninety-five percent (95\%) agreed that there was ample opportunity to get assistance from the instructor via office hours, telephone, email or the website. Most of the students (82\%) agreed that they the educator was able to explain concepts to assist understanding. Ten percent (15\%) disagreed. The others $(5 \%)$ had some face-to-face interaction with the educator $(\mathrm{X} 2=27.6, \mathrm{p}<.005)$.

\section{Organization of Material/Teaching Methods}

\begin{tabular}{|l|l|}
\hline \multicolumn{2}{|c|}{ Table 5 } \\
The interactive teaching/learning activities are well organized \\
\hline Strongly Agree & $35 \%$ \\
\hline Agree & $37 \%$ \\
\hline Disagree & $15 \%$ \\
\hline Strongly Disagree & $9 \%$ \\
\hline N/A & $4 \%$ \\
\hline & \\
\hline
\end{tabular}

\section{Table 6}

The course material was presented in a logical sequence

\begin{tabular}{|l|l|}
\hline Strongly Agree & $37 \%$ \\
\hline Agree & $52 \%$ \\
\hline Disagree & $7 \%$ \\
\hline Strongly Disagree & $4 \%$ \\
\hline
\end{tabular}

Eighty-five percent (85\%) thought that the course work was presented in a logical sequence, but fewer felt that the teaching/learning activities were well organized ( $72 \%)$ (not a significant difference). When PowerPoint presentation software was used as a tool, eighty-five percent (85\%) agreed that it was helpful. 


\section{Format Affects Lèarning Methods}

Students agreed that the online course format encourages independent thinking and critical thinking about issues related to the content (Strongly Agree 29\%; Agree $67 \%)$. They agreed even more strongly that students are encouraged to become personally involved in the learning process (Strongly Agree 48\%; Agree 47\%).

\section{Course Content}

There was a general consensus that the on-line course encouraged development of the skills needed for their education, that the instruction was at the appropriate level and current and that the course materials reinforced the learning process. At least $85 \%$ of the students concurred with these statements.

\section{Acceptance of Method}

\section{Table 7}

Overall, how would you rate this course?

\begin{tabular}{|l|l|}
\hline Excellent & $24 \%$ \\
\hline Very Good & $48 \%$ \\
\hline Good & $9 \%$ \\
\hline Fair & $14 \%$ \\
\hline Poor & $5 \%$ \\
\hline
\end{tabular}

\section{Table 8}

I would take another course that used this technology

\begin{tabular}{|l|l|}
\hline Strongly Agree & $48 \%$ \\
\hline Agree & $30 \%$ \\
\hline Disagree & $13 \%$ \\
\hline Strongly Disagree & $7 \%$ \\
\hline N/A & $0 \%$ \\
\hline
\end{tabular}


Although most of the students were positive about their experiences, there were a few students who were unhappy with the online class and would not take another on-line class. To determine what factors might be associated with a poor evaluation, the data was analyzed further with respect to the employment status of the students, the student's ethnicity, and age of the student.

\section{Work Status}

\begin{tabular}{|c|c|c|c|c|}
\hline & Full Time & Part Time & Unemployed & Total \\
\hline Agree & 6 & 2 & 14 & 22 \\
\hline Agree & 3 & 6 & 4 & 13 \\
\hline Disagree & 1 & 1 & 4 & 6 \\
\hline $\begin{array}{l}\text { Strongly } \\
\text { Disagree }\end{array}$ & $\begin{array}{r}1 \\
11\end{array}$ & $\begin{array}{r}2 \\
11\end{array}$ & $\begin{array}{r}0 \\
22\end{array}$ & $\begin{array}{l}3 \\
44\end{array}$ \\
\hline
\end{tabular}

Those who said that they would not take the course again were evenly divided between not employed, part-time employment and full time employment. Work status does not appear to affect whether a student is willing to take an online course again.

\section{Adjusting for Race:}

$\begin{array}{lrllr}\begin{array}{l}\text { I would take another course that used this technology } \\ \text { White }\end{array} & \text { Hispanic } & \text { Asian/Pacific Islander } \\ \text { Strongly } & 16 & & 4 & 2 \\ \text { Agree } & 10 & & & 4 \\ \text { Agree } & 5 & 1 & 0 \\ \text { Disagree } & 1 & & 1 \\ \text { Strongly } & & 5 & 7 \\ \text { Disagree } & 32 & & 5\end{array}$

There was no difference by race in this sample as to willingness to repeat the online class experience. Each of the three racial groups had over $80 \%$ willing to repeat the experience. Caucasian students were likely to take another online course (81\%). Eighty percent (80\%) of the Hispanic students want to take another online course. Eighty six percent (86\%) of the Asian-Pacific students would take another online course. 


\begin{tabular}{|l|l|c|c|c|}
\hline \multicolumn{6}{|l|}{ Table 9 } \\
\hline & White & Hispanic & $\begin{array}{c}\text { Asian/Pacific } \\
\text { Islander }\end{array}$ & Total \\
\hline Excellent & 9 & 1 & 1 & 11 \\
\hline Very Good & 10 & 1 & 1 & 12 \\
\hline Good & 3 & 2 & 2 & 7 \\
\hline Fair & 7 & 0 & 2 & 9 \\
\hline Poor & 3 & 1 & 1 & 5 \\
\hline Total & 32 & 5 & 7 & 44 \\
\hline
\end{tabular}

The data shows that there were no significant differences in rating the online classes by race.

Table 10

I would take another course that used this technology Age $\quad 30$ and under

Over 30

Strongly Agree

Agree

Disagree

Strongly Disagree

Total
10

11

2

0

23
12

4

4

3

23

Overall, empirical data for the results was skewed towards the Agree/Strongly Agree end of the survey. Acceptance of on-line courses is high. Although not every individual was equally enthusiastic, eighty five percent (85\%) of the students were willing to take another on-line course. In this study, ethnicity, age, or work status did not significantly affect whether a student was willing to take another on-line course.

However, all of the students who indicated that they would not take another online course were over 50 years of age. 


\section{Student Responses to Open-ended Questions}

Students' comments are revealing and suggest areas for possible future study.

These comments suggest that the response to the online course was related to the educator's ability to organize the material and work with the technology rather than the content of the course. Because anonymity was guaranteed, there was no way to correlate responses with a particular course or educator. However, it does suggest and possibly confirm that there may be special skills involved when teaching an online course.

"This course and instructor have been my best online experiences. In the past I have not been as lucky. Most of the time the courses were unorganized and it was impossible to communicate with the instructor."

"The instructor was not technically capable of providing the assistance I needed. The material was not organized."

"I would only take an online course if I knew the instructor is organized. I have taken other online courses prior to this one and the organization the instructors used for the classes were confusing and it was difficult to find assignments."

Other students commented on their reactions to the course material and online learning modalities. These responses included increased workload due to extra reading and writing required by online courses, omission of live discussions, as well as increased anxiety levels.

"The personal involvement required is far more than I have experienced in regular classes. Overall, this forces me to try to better articulate my views... There seems to be a higher level of anxiety for students in my online class because of how much actual reading and writing is necessary over a short amount of time."

"I felt it eliminated one important modality for learning-hearing the information from the professor. I had to rely on either reading it myself or talking with classmates about it online and watching videos, but was missing that critical element of hearing the professor talk about it. That helps me learn." 


\section{Conclusion}

Overall, acceptance of on-line courses is high. Most of the students were willing to take another online course in the future. Respondents felt that the internet course offered more flexibility than a traditional classroom setting. Although some students felt that they were unable to develop a personal relationship with their instructor, almost all agreed that there was ample opportunity to get assistance from the educator, and that the educator was able to explain concepts to assist their understanding. There was a general consensus that the on-line course encouraged development of the skills needed for their education, that the instruction was both current and at the appropriate level, and that the course materials reinforced the learning process. Almost all of the respondents felt that that the online course format encouraged them to become personally involved in the learning process and encouraged both independent and critical thinking skills.

Student responses to open-ended questions suggest possible areas for further study to improve online education. Students identified the educator's organization and technical skills as qualities vital to successful online instruction. Some other responses included students' increased workload due to extra reading and writing required by online courses and increased anxiety levels. These responses suggest a need to further study online education.

This study is limited in the extent to which conclusions can be generalized to the population from which the sample is selected as it does not employ random sampling and includes a relatively small sample size. Because subjects are not drawn by chance from a larger identified pool, the generalizability or external validity of the findings is limited. The self-selection of the sample limits this study; many of the students who might be 
extreme examples were likely not to take part in the study or may drop out of the online courses early. The issues inherent to self-reporting pose a limitation of this study. The satisfaction level reported by students may vary considerably throughout the course. The students' rating and perception of their satisfaction at the point that the questionnaires are administered may not be representative of their experiences throughout the course.

The findings of this study are too small to find statistically significant differences and are intended as a pilot study to suggest further research. Students and faculty will benefit from the study by helping to facilitate improvements in order to ensure quality online education. 


\section{$\therefore \quad$ References}

American Association of Colleges of Nursing. (2007). Fact sheet: Nursing shortage.

Retrieved February, 24, 2008, from

http://www.aacn.nche.edu/Media/FactSheets/facutlyshortage.htm.

Bata-Jones, B. \& Avery, M.D. (2004). Teaching pharmacology to graduate nursing students; evaluation and comparison of web-based and face-to-face methods. Journal of Nursing Education, 43, 185-189.

Billings, D.M. (2000). A framework for assessing outcomes and practices in Web-based courses in nursing. Journal of Nursing Education, 39, 60-66.

Buckley, K.M. (2003). Evaluation of classroom-based, web-enhance, and web-based distance learning nutrition courses for undergraduate nursing. Journal of Nursing Education, 42, 367-370.

Davenport, J. (1984). Andragogy: another bandwagon or legitimate tool in the continuing education armamentarium? International Journal of Lifelong Education. 8, 108-117.

Davenport, J. (1985). Knowles or Lindeman: would the real father of American andragogy please stand up. Lifelong Learning. 9, 4-5.

Diekelmann, N., \& Schulte, H.D. (2000). Technology-based distance education and the absence of physical presence. Journal of Nursing Education, 39; $51-52$.

Fearing, A. \& Riley, M. (2005). Graduate students' perceptions of online teaching and relationship to preferred learning styles. MedSurg Nursing, 14(6), 383-389.

Fisher J. \& Podeschi, R.(1989). From Lindeman to Knowles: a change in vision. International Journal of Lifelong Education, 8, 345-353. 
Halstead, J.A., \& Coudret, N.A. (2000). Implementing web-based instruction in a school of nursing: implications for faculty and students. Journal of Professional Nursing, $16,273-281$.

Hyde, A. \& Murray, M. (2005). Nurses' experiences of distance education programs. Journal of Advanced Nursing, 49, 87-95.

Jang, K., Hwang, S., Park, S.J., Kim, Y.S., \& Kim, M.J. (2005). Effects of web-based teaching method on undergraduate nursing students' learning of electrocardiography. Journal of Nursing Education, 44, 35-39.

Kenny, A. (2002). Online learning; enhancing nurse education? Journal of Advanced Nursing, 38, 127-135.

Kumrow, D.E. (2005). Evidence-based strategies of graduate students to achieve success in a hybrid web-based course. Journal of Nursing Education, 46, 140-145.

Leasure, A.R., Davis, L. \& Thievon, S.L. (2000). Comparison of student outcomes and preferences in a traditional vs. World Wide Web-based bacçalaureate nursing research course. Journal of Nursing Education, 39, 149-154.

Lewis, P. \& Price, S. (2007). Distance education and the integration of e-learning in a graduate program. The Journal of Continuing Education in Nursing, 38, 139-143.

Magnussen, L. (2006). Applying the principles of significant learning in the e-learning environment. Journal of Nursing Education, 47, 82-87.

Mancuso-Murphy, J. (2006). Distance education in nursing: an integrated review of online nursing students' experiences with technology-delivered instruction. Journal of Nursing Education, 46, 252-260. 
O’Neil, C. \& Fisher, C. (2008). Should I take this course online? Jburnal of Nursing Education, 47, 53-58.

Pyron, T., Cline, G., Tews, D. \& Parker, M. (2003). The local public health accreditation program: many partners-one vision. Journal of Public Health Management \& Practice, 9(3):228-234.

Salyers, V. (2007). Teaching psychomotor skills to beginning nursing students using a web-enhanced approach: a quasi-experimental study. International Journal of Nursing Education Scholarship, 4, 1-12.

Seiler, K. \& Bilings, D. (2004). Student experiences in web-based nursing courses: benchmarking best practices. International Journal of Nursing Education Scholarship, 1, 21-22.

Sit, J.W., Chung, J.W., Chow, M.C., \& Wong, T.K. (2005). Experiences of online learning; students' perspective. Nurse Education Today, 25, 140-147.

Shovein, J., Huston, C., Fox, S., \& Damazo, B. (2005). Challenging traditional teaching and learning paradigms: online learning and emancipatory teaching. Nursing Education Perspectives, 26, 340-343.

Teeley, K.H. (2007). Designing hybrid web-based coursed for accelerated nursing students. Journal of Nursing Education, 46, 417-422.

Tennant, M. (1988). An evaluation of Knowles's theory of adult learning. International Journal of Lifelong Education. 5, 113-122.

Thiele, J.E. (2002). Learning patterns of online students. Journal of Nursing Education, 42, 364-366. 
Wills, C. \& Stommel, M. (2002). Graduate students' pre-course and post-course perceptions and preferences concerning completely web-based courses. Journal of Nursing Education, 41, 193-201.

Woo, M.A., \& Kimmick, J.V. (2000). Comparison of internet versus lecture instructional methods for teaching nursing research. Journal of Professional Nursing, 16, 132139. 
You have successfully submitted your manuscript, Perceptions Among Students in Ontine Health Related Courses - A Pilot Study. Your Manuscript Number is:

Take note of this number for future reference. You can log on at any time to see the current status of your manuscript(s). The web address is http://www.rapidreview.com and your username is

If you wish to contact the journal office, here's how:

Journal of Nursing Education

SLACK Incorporated

6900 Grove Road

Thorofare, NJ 08086

USA

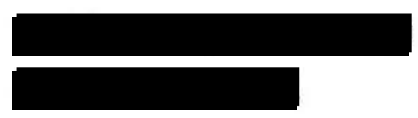

The JOURNAL OF NURSING EDUCATION is supported almost solely by subscriptions from nurse educators like you. Your or your institution's support is important to us. Subscribe by going to www.slackinc.com/subscribetoday or requesting your library carry this valuable title.

Thank you for your submission.

Jaime Harker, ELS

Managing Editor

Journal of Nursing Education 